\title{
Felty's syndrome
}

\section{Clinical and serological analysis of 34 cases}

\author{
C. W. SIENKNECHT, M. B. UROWITZ, W. PRUZANSKI, AND H. B. STEIN \\ From the University of Toronto, Rheumatic Disease Unit, Wellesley Hospital, Toronto, Canada
}

SUMMARY Review of 34 cases of Felty's syndrome showed this to be a form of 'super' rheumatoid disease because of the severity of joint disease, the prominence of extra-articular features, and the remarkable incidence of infection. The response to splenectomy in these 34 patients was shown by a return towards normal of peripheral blood abnormalities and a decrease in bone marrow granulopoiesis. Although some patients remained free of infection after splenectomy, others have continued 8 to have infections despite the return of white blood cell counts to normal levels. Although splenectomy 음 and subsequent increase in white blood cell levels may be beneficial, our experience suggests that other factors are important in the susceptibility to infection of Felty's syndrome patients. Moreover, we think that splenectomy may have been instrumental in the fatal infection of one of our patients.

There has been a greater awareness of the clinical syndrome of rheumatoid arthritis, leucopenia, and splenomegaly since Felty described his 5 patients in 1924. Although the association of splenomegaly, leucopenia, and increased frequency of infections is well recognized, these features do not always present together in one patient, thus excluding a simple cause and effect explanation. Furthermore, several aspects of the clinical course of Felty's syndrome remain unclear, for example the features of the articular and extra-articular disease, the aetiology of the leucopenia, the role of splenectomy, the duration of leucocytosis, and the frequency of infections after splenectomy. We attempted to answer these questions by reviewing 34 cases with Felty's syndrome observed for a mean of 56 months.

\section{Materials and methods}

Thirty-four patients with Felty's syndrome at the Wellesley Hospital were selected for study. They fulfilled all of the following criteria. (1) Classical or definite rheumatoid arthritis (ARA criteria). (2) Splenomegaly as detected by physical examination or by radioisotope scan. (3) Leucopenia of $<4.0 \times 10^{9} / 1$, or neutropenia of $<2.0 \times 10^{9} / 1$, or thrombocytopenia of $<100 \times 10^{9} / 1$. (4) No other

Accepted for publication April 29, 1977

Correspondence to Dr. M. B. Urowitz, Wellesley Hospital, 659 Rheumatic Disease Unit, 160 Wellesley Street East, Toronto, Canada M4Y 1J3 known causes for the cytopenia (e.g. drugs) or the $\vec{\varphi}$ splenomegaly (e.g. lymphoma).

All patients were evaluated at the time of diagnos of Felty's syndrome, and 27 were still being fol lowed. 4 died and 3 have been lost to follow-up. Splenectomy had been performed in 12 of these patients. A detailed clinical and laboratory evalua- $\frac{\circ}{\mathbb{D}}$ tion according to a predesigned protocol was carried $\stackrel{2}{\Rightarrow}$ out on 18 of these patients in the first half of 1975. The level of joint inflammatory activity was estimated according to the articular index method of Lansbury (1972), and by a count of inflamed joints and of synovial effusions. The severity of destruction in each joint was scored from stage $1+$ to $3+\frac{j}{3}$ according to the method of Steinbrocker et al. (1949) and all those with $2+$ or $3+$ were considered to have $\delta$ advanced joint destruction. $X$-rays of the hands and $₹$ feet were evaluated according to the method of $ᄋ$ Kellgren et al. (1963) and those with stage III and $D$ IV were tabulated.

Bone marrow aspirations were performed in 30 patients at the time of diagnosis and evaluated by an independent assessor. Serological tests included $\tilde{O}$ latex fixation for rheumatoid factor, fluorescent $\stackrel{N}{\omega}$ antinuclear antibody test, total haemolytic comple- -2 ment, C3, cellulose acetate electrophoresis, quantita-o tion of immunoglobulins (IgG, $\operatorname{IgA}, \operatorname{IgM}$ ), and $\overparen{\varnothing}$ DNA-binding by the Farr technique using ${ }^{125} \mathrm{I} . \stackrel{?}{+}$ Intradermal skin tests using SKSD (10 U SK and 7 $2 \cdot 5 \mathrm{U} \mathrm{SD} / 0 \cdot 1 \mathrm{ml})$, PPD (5 U), Candida (1/100), and Trichophyton $(1 / 30)$ were performed and the 
induration measured in mm 48 hours after application. Peripheral blood B and T lymphocyte populations were estimated by immune (Bianco et al., 1970) and nonimmune (Jondal et al., 1972) sheep erythrocyte rosette formation, respectively, in 8 patients. In vitro lymphocyte responses to phytohaemagglutinin, pokeweed mitogen, and concanavalin A were determined by estimating the incorporation of ${ }^{3} \mathrm{H}$-thymidine into the DNA of blast cells (Greaves et al., 1974). These mitogen studies were performed before skin testing in 10 patients. Results are expressed as ratios of values compared with those of age- and sex-matched controls.

The coil test as described by Jensen et al. (1973) was used to study neutrophil kinetics in 7 Felty's patients ( 2 had had splenectomy), in 1 rheumatoid patient without Felty's, and in 2 normal subjects. Blood was withdrawn from each subject and approximately $500 \mathrm{ml}$ blood was run into a Gambro dialyser with a $13.5 \mu \mathrm{m}$ membrane (purchased from Gambro Lundia, Mississauga, Ontario). When the coil was filled the blood was allowed to stagnate for 30 minutes and then was infused back into the subject. Blood specimens for total white blood cell count and differentials were drawn from the opposite arm immediately before and after the original sample was taken, immediately before reinfusion of the coil blood and at 5, 15, 30, and 45 minutes, and 1,2 , 3 , and 4 hours after the reinfusion was begun. The mean of the three preinfusion blood counts was taken as the baseline value for the neutrophil counts. The peak count was the highest recorded after the reinfusion was begun. The per cent increase in the neutrophil count after reinfusion was calculated by the formula:

$$
\frac{\text { peak count }- \text { baseline count }}{\text { baseline count }}=\% \text { increase. }
$$

\section{Results}

\section{CLINICAL EVALUATION}

Of the 34 patients with Felty's syndrome, 23 (68\%) were females and $11(32 \%)$ were males. The mean age at onset of the rheumatoid arthritis was 39 years (range 15-67 years), whereas the mean age at diagnosis of Felty's syndrome was 56 (range 41-72) years. Diagnosis of Felty's syndrome followed the onset of rheumatoid arthritis by a mean of 16.7 (range 0-38) years. Follow-up ranged from 3 months to 11 years (mean 4.7 years).

In Tables 1, 3, 4, describing the clinical and laboratory features of the patients with Felty's syndrome, comparison was made when possible with two previous studies of Felty's syndrome (Ruderman et al., 1968; Barnes et al., 1971) and with a large group of patients (127) with definite or classical rheumatoid arthritis severe enough to be admitted for treatment (Gordon et al., 1973).

At the time of diagnosis of Felty's syndrome, $87 \%$ of the patients had active arthritis (Table 1). The mean $( \pm S D)$ number of active joints, effusions, and articular index were $20 \cdot 6 \pm 12 \cdot 8(\mathrm{n}=26), 2 \cdot 8 \pm 3 \cdot 5$ $(\mathrm{n}=22)$, and $92 \cdot 6 \pm 52 \cdot 1 \quad(\mathrm{n}=21)$, respectively. Joint destruction was found in $91 \%$. Evaluation of hand $x$-rays showed stage 4 changes in 16 patients, stage 3 in 9 , stage 2 in 6 , stage 1 in 1 , and stage 0 in 1 (Table 1).

Extra-articular manifestations of rheumatoid disease in addition to Felty's syndrome and anaemia were present in all but 2 patients, the mean number per patient being $2 \cdot 9$ (Tables 2,3 ). Rheumatoid

Table 1 Articular features of 34 patients with Felty's syndrome compared with 127 hospitalized RA controls*

\begin{tabular}{lll}
\hline & Felty's & RA controls \\
\hline Articular index & 93 & 61 \\
Synovial effusions (\%) & 77 & 55 \\
Effusions/patient (n) & $2 \cdot 8$ & - \\
Active joint count (n) & 21 & - \\
Incidence of active arthritis (\%) & 87 & - \\
Joint destruction 2-3+ (\%) & 91 & 55 \\
$X$-ray stage III \& IV (\%) & 74 & 41 \\
\hline
\end{tabular}

*Gordon et al. (1973).

Table 2 Number of extra-articular features in patients with Felty's syndrome (excluding Felty's syndrome and anaemia)

\begin{tabular}{llllllll}
\hline No. of features & 0 & 1 & 2 & 3 & 4 & 5 & 6 \\
\hline No. of patients & 2 & 6 & 7 & 7 & 6 & 4 & 2 \\
\hline Mean $=2 \cdot 9 /$ patient & & & & & &
\end{tabular}

Table 3 Clinical features in 34 patients with Felty's syndrome compared with previous series* and $R A$ controls $\dagger$

\begin{tabular}{lrrrl}
\hline Features & $\begin{array}{l}\text { Present } \\
\text { study } \\
(\%)\end{array}$ & $\begin{array}{l}\text { Ruderman } \\
(\%)\end{array}$ & $\begin{array}{l}\text { Barnes } \\
(\%)\end{array}$ & $\begin{array}{l}\text { RA controls } \\
(\%)\end{array}$ \\
\hline Rheumatoid nodules & 74 & 82 & 71 & 53 \\
Splenomegaly & 100 & 100 & 100 & 12 \\
Lymphadenopathy & 42 & 30 & 19 & 12 \\
Hepatomegaly & 68 & - & - & - \\
Leg ulcers & 16 & 41 & 19 & - \\
Peripheral neuropathy & 14 & 19 & 24 & 10 \\
Sjøgren's & 48 & - & 69 & - \\
Episcleritis & 3 & 11 & 5 & 9 \\
Pericarditis & 0 & 7 & 0 & 2 \\
Pleuritis & 22 & 15 & 0 & - \\
Pulmonary fibrosis & 50 & - & - & 20 \\
\hline
\end{tabular}

* Ruderman et al., (1968); Barnes et al., (1971).

+Gordon et al., (1973).

$-=$ means not ascertained. 
nodules developed in $20 / 27$ patients ( $74 \%$ ). Splenomegaly, present in all patients by definition, was detected in 30 patients by palpation and in 4 by radioisotope scanning. Hepatomegaly and lymphadenopathy were present in $23 / 34(68 \%)$ and $14 / 33$ (42\%) patients respectively. Systemic symptoms including fever and substantial weight loss $(>10 \%)$ occurred in $22 / 34(65 \%)$ patients. Leg ulcers and skin pigmentation were present in $5 / 31(16 \%)$ and $7 / 32(22 \%)$ patients, pigmentation accompanying 4 of the 5 leg ulcers. Sjøgren's syndrome was diagnosed in 13/27 (48\%) patients using Schirmer's test. Abnormalities of the nasal septum were found in $8 / 27(30 \%)$ patients: perforation 1 , ulceration 3 , and erythema 4. Ocular disorders in addition to Sjøgren's syndrome occurred in 13/34 (38\%) patients: 8 instances of conjunctivitis, 4 of cataracts, 1 of episcleritis, and 3 of unilaterally irregular pupils. Of the 8 patients with conjunctivitis 6 had Sjøgren's syndrome.

No examples of cardiac lesions definitely attributable to rheumatoid disease were found. However, 4 patients had hypertensive heart disease, 4 ischaemic heart disease, 3 unexplained cardiomegaly, and 6 nonspecific electrocardiographic changes. Type IV hyperlipidaemia was present in 5 patients. Pulmonary fibrosis and pleurisy were detected in $16 / 32$ $(50 \%)$ and $7 / 32(22 \%)$, respectively. Other pulmonary lesions included atelectasis in 4, Ghon complex in 3, apical infiltrates or scarring in 3, nodules in 2 , and a cavitary lesion in 1 . Noncompressive neuropathies occurred in 4/29 (14\%) patients. Proximal muscle weakness in $10 / 30(33 \%)$ patients was associated with raised creatine phosphokinase in only one. Six neoplasms occurred in 5 patients, including one case each of squamous cell carcinoma of the skin, basal cell carcinoma of the scalp, malignant melanoma, adenocarcinoma of colon, lymphosarcoma, and chronic lymphocytic leukaemia. A further patient may have multiple myeloma.

Of the 4 patients who died, only the one with chronic lymphocytic leukaemia had had a splenectomy. One patient died from bronchopneumonia superimposed on lungs markedly affected by fibrosis and amyloidosis, the latter also affecting the liver and gastrointestinal tract. A third patient died of generalized inanition, and the fourth of myocardial infarction.

\section{LABORATORY EVALUATION}

The erythrocyte sedimentation rate (ESR, Westergren) (Table 4) at diagnosis was $85 \pm 31$ (SD) $\mathrm{mm} / \mathrm{h} .27$ of the 34 patients were anaemic, the mean haemoglobin being $11 \cdot 1 \pm 2 \cdot 0$ (SD) $\mathrm{g} / \mathrm{dl}$. The mean highest recorded reticulocyte count was $3 \cdot 2 \%$
Table 4 Laboratory features in 34 patients with Felty' syndrome compared with previous series* and $R A$ controls $\dagger$

\begin{tabular}{|c|c|c|c|c|}
\hline & $\begin{array}{l}\text { Present } \\
\text { study }\end{array}$ & Ruderman & Barnes & $R A$ controls \\
\hline $\begin{array}{l}\mathrm{Hb}(\mathrm{g} / \mathrm{dl} \text { or } \%) \\
\text { WBC (lowest mean) }\end{array}$ & $11 \cdot 1$ & $31 \%$ & $31 \%$ & $9 \cdot 6$ \\
\hline $\begin{array}{c}\left(\times 10^{9} / 1\right) \\
\text { Granulocytes }\end{array}$ & $2 \cdot 138$ & $1 \cdot 74$ & $1 \cdot 545$ & $8 \cdot 2$ \\
\hline $\begin{array}{l}\text { (lowest mean) } \\
\left(\times 10^{9} / 1\right)\end{array}$ & 0.894 & $0 \cdot 77$ & 0.422 & 一 \\
\hline Reticulocytes (\%) & $3 \cdot 2$ & $4 \cdot 0$ & $4 \cdot 0$ & - \\
\hline $\operatorname{ESR}(\mathrm{mm} / \mathrm{h})$ & 85 & - & - & 一 \\
\hline $\begin{array}{l}\text { Platelets } \\
\text { (lowest mean) }\end{array}$ & & & & \\
\hline $\begin{array}{l}(\times 109 / 1) \\
\text { 24-hour urine protein }\end{array}$ & 195 & 172 & 166 & 一 \\
\hline $\begin{array}{l}(>500 \mathrm{mg})(\%) \\
\text { Serum albumin }\end{array}$ & $39 \%$ & - & - & - \\
\hline $\begin{array}{l}\text { (mean, } \mathbf{g} / \mathbf{l}) \\
\text { Serum globulin }\end{array}$ & 31 & - & 37 & 一 \\
\hline (mean, g/l) & 19 & 26 & - & - \\
\hline RF titre (mean) & $1: 2898$ & $1: 3520$ & & \\
\hline$\%$ positive & 100 & 100 & 90 & 93 \\
\hline LE positive (\%) & $41 \%$ & $12 \cdot 5$ & 25 & 17 \\
\hline ANF positive $(\%)$ & 55 & 85 & 61 & $\overline{11}$ \\
\hline IgG (mean, g/l) & $12 \cdot 91$ & $22 \cdot 97$ & - & $11 \cdot 48$ \\
\hline IgA (mean, g/l) & $3 \cdot 56$ & $6 \cdot 06$ & - & $2 \cdot 92$ \\
\hline IgM (mean, $g / 1$ ) & $8 \cdot 32$ & $2 \cdot 75$ & - & $1 \cdot 78$ \\
\hline $\begin{array}{l}\text { Total haemolytic } \\
\text { complement }\end{array}$ & 177 & $\begin{array}{l}111 \% \\
\text { of control }\end{array}$ & & \\
\hline
\end{tabular}

* Ruderman et al. (1968); Barnes et al., (1971).

tGordon et al. (1973).

$-=$ means not ascertained.

(range $0 \cdot 4-6 \cdot 1 \%$ ). 12 of 15 patients had low seruno iron concentrations (mean $41 \cdot 3 \pm 29 \cdot 7 \mu \mathrm{g} / 100 \mathrm{ml}$ \% $7 \cdot 4 \pm 5 \cdot 3 \mu \mathrm{mol} / \mathrm{l})$ and $2 / 15 \mathrm{had}$ a raised iron binding capacity (mean $319 \pm 54 \mu \mathrm{g} / 100 \mathrm{ml} ; 57 \pm 9 \cdot 7 \mu \mathrm{mol} / 1$ ) All but one patient was leucopenic (lowest mean recorded value $\left.2 \cdot 14 \pm 1 \cdot 06(\mathrm{SD}) \times 10^{9} / 1\right)$, and $29 / 33^{\circ}$ patients were neutropenic including the patient who was not leucopenic. The mean $( \pm \mathrm{SD})$ lymphocyte monocyte, and eosinophil counts were $0.9 \pm 0.83$ ? $0.11 \pm 0.08,0.07 \pm 0.08 \times 10^{9} / 1$. All but one patieng was lymphocytopenic $\left(<1.5 \times 10^{9} / 1\right)$ and none ha更 eosinophilia. Thrombocytopenia $(<100$ platelets $\left.\times 10^{9} / 1\right)$ was present in $5 / 33$ patients, the mean lowest platelet count being $195 \pm 108 \times 10^{9} / 1$.

Bone marrow aspirations performed on 30 of the patients at the time of diagnosis (Table 5) showee hypercellularity in most instances. In $90 \%$ of marrows granulopoiesis was accelerated or normal with a left shift in $60 \%$. A surprising finding was lack of iron staining in $67 \%$ of patients. Patients were thought to be losing blood through the rectum if 3 or more stool specimens gave a $2+$ of greater guaiac result. 5 of 13 patients were thuso losing blood through the rectum at the time of stoo $\bar{\Phi}$ examination. 
Table 5 Presplenectomy bone marrow studies in 30 patients

\begin{tabular}{|c|c|c|c|c|c|}
\hline & $\begin{array}{l}\text { None } \\
(n)\end{array}$ & $\begin{array}{l}\text { Decreased } \\
\text { (n) }\end{array}$ & $\begin{array}{l}\text { Normal } \\
(n)\end{array}$ & $\begin{array}{l}\text { Increased } \\
(n)\end{array}$ & $\begin{array}{l}\text { Not } \\
\text { recorded } \\
(n)\end{array}$ \\
\hline $\begin{array}{l}\text { Cellularity } \\
\text { Erythropoiesis } \\
\text { Granulopoiesis } \\
\text { Mature } \\
\text { granulocytes } \\
\text { Megakaryocytes } \\
\text { Iron stain }\end{array}$ & $\begin{array}{l}- \\
- \\
1(3 \%) \\
20(67 \%)\end{array}$ & $\begin{array}{c}3(10 \%) \\
1(3 \%) \\
3(10 \%) \\
17(57 \%) \\
2(7 \%) \\
5(17 \%)\end{array}$ & $\begin{array}{c}5(17 \%) \\
7(23 \%) \\
6(20 \%) \\
12(40 \%) \\
15(50 \%) \\
2(7 \%)\end{array}$ & $\begin{array}{c}20(57 \%) \\
22(73 \%) \\
21(70 \%) \\
- \\
13(43 \%) \\
3(10 \%)\end{array}$ & $\begin{array}{c}2(7 \%) \\
- \\
- \\
- \\
-\end{array}$ \\
\hline
\end{tabular}

$-=$ means not ascertained.

Liver function tests were not uncommonly abnormal. Alkaline phosphatase was increased in 7/31 $(23 \%)$ patients. Raised aspartate transaminase (SGOT) or alanine transaminase (SGPT) was found in 6 patients, one of whom also had a raised alkaline phosphatase. Only $1 / 26$ patients had a mildly raised serum bilirubin level. Sulphobromophthalein excretion after 45 minutes was abnormal in 6/22 $(27 \%)$ patients, 4 of whom had abnormal liver enzymes. A prolonged prothrombin time and prolonged partial thromboplastin time were present in $4 / 27(15 \%)$ and $10 / 19(53 \%)$ patients, respectively. Mean serum albumin and gammaglobulin levels were $31 \pm 6$ and $19 \pm 8 \mathrm{~g} / \mathrm{l}$ respectively (Table 4). 15 of $34(44 \%)$ patients were hypergammaglobulinaemic. Liver specimens (biopsy 6, autopsy 1) showed lipoid granulomata in 2 (normal liver enzymes), increased fatty infiltration in 2 (raised alkaline phosphatase in 1), lobular hepatitis in 1 (raised SGOT and SGPT), simple liver cyst with normal parenchyma in 1 (raised alkaline phosphatase), and haemangiomata, amyloidosis, and liver congestion in the autopsy specimen. No cirrhosis or oesophageal varices were found in our patients.

Spleens from 12 splenectomies and 1 autopsy were examined. Spleen masses ranged from 210 to $1650 \mathrm{~g}$, with no correlation to the degree of cytopenia. A subcapsular infarct was present in one patient and a subcapsular haematoma in another. An accessory spleen was removed in one case. Lipoid granulomata were present in the spleen of one patient and were also found in the liver. Aggregates of lipid-filled macrophages were present in another spleen. Venous sinusoids were congested in 7 spleens but sinus cell hyperplasia was not present. Reticulum cell hyperplasia was found in 2 specimens. Lymphoid tissue in 2 cases showed germinal centre hyperplasia. No amyloidosis was present in any of the spleens.

Thirty-one patients had at least one 24-hour urine collection for protein estimation. $25(81 \%)$ excreted protein $>200 \mathrm{mg} / 24$ hours. Proteinuria $>500 \mathrm{mg}$ and $1000 \mathrm{mg} /$ day was found in $12 / 31(39 \%)$ and $4 / 31(13 \%)$ patients, respectively (Table 4$)$. No significantly abnormal urinary sediment was associated with these changes in most cases. Renal function tests in 22 patients showed a mean serum creatinine of $0.91 \mathrm{mg} / 100 \mathrm{ml}(80.5 \mu \mathrm{mol} / \mathrm{l})$ and a creatinine clearance of $82 \mathrm{ml} / \mathrm{min}$. Only $2 / 29$ patients had been taking potentially nephrotoxic drugs within 3 months of the assessments. Renal histology was available for 3. Focal glomerulonephritis and ischaemic changes due to arteriosclerosis was present in one patient with $>4.0 \mathrm{~g}$ protein $/ 24$ hours. Another patient with proteinuria had mild glomerular alterations with hypercellularity and increased mesangial matrix. Immunofluorescence was negative but electron microscopy showed fusion of the foot processes of the epithelial cells. The third specimen, taken post mortem from the kidney of the patient with amyloidosis, showed arterial and arteriolar nephrosclerosis but no amyloidosis though there was significant proteinuria.

\section{IMMUNOLOGICAL EVALUATION (TABLE 4)}

All patients had rheumatoid factor as determined by the latex fixation test. With no titre being diluted out to $>1 / 5120$, the mean titre was $1 / 2898 \pm 1 / 1945$ (SD). A titre of $>1 / 640$ was present in $29 / 34$ patients. LE cells were detected in 11/27 (41\%) patients and a positive antinuclear factor was present in $16 / 29(55 \%)$. DNA-binding was not raised in the 8 patients in whom the test was performed, including 2 patients with antinuclear factor. Hypocomplementaemia was present in $2 / 22(9 \%)$ patients. The mean total haemolytic complement was $177 \pm 42$ units (normal 130-220) and the mean C3 $1 \cdot 25 \pm 0 \cdot 33 \mathrm{~g} / 1$ (normal $1 \cdot 25-1 \cdot 65 \mathrm{~g} / \mathrm{l}$ ). VDRL was negative in all 21 patients tested.

Circulating B lymphocytes detected by the EACrosette technique in 8 patients numbered $27 \% \pm 11$ (absolute number $0.758 \pm 0.827$ cells $\times 10^{9} / \mathrm{l}$ ) compared to $28 \% \pm 9$ (abs. no. $0 \cdot 594 \pm 0 \cdot 262 \times 10^{9} / \mathrm{l}$ ) in the controls. Immunoglobulin determinations in 18 patients showed raised IgG in $6(33 \%)$, IgM in $13(72 \%)$, and $\operatorname{IgA}$ in $10(56 \%)$. Circulating $\mathrm{T}$ lymphocytes as determined by the E-rosette technique in 8 patients numbered $62 \% \pm 8$ (abs. no. $1658 \pm 1773 / \mathrm{mm}^{3}$ ), compared to $61 \% \pm 9$ (abs. no. $\left.1327 \pm 397 / \mathrm{mm}^{3}\right)$ in the controls.

Anergy as determined by the four skin tests was present in $4 / 16(25 \%)$ patients. In the mitogen studies, the mean $( \pm \mathrm{SD})$ results for phytohaemagglutinin (PHA), concanavalin A (Con A), and pokeweed mitogen (PWM), expressed as a ratio of patient to control, in 10 patients were $0.9 \pm 0.3$, 
$0 \cdot 8 \pm 0 \cdot 6$, and $1 \cdot 0 \pm 0 \cdot 5$, respectively. Of these 10 patients, 3 were tested after splenectomy. PHA stimulation was considered to be significantly low in 2 , both of whom had had splenectomies. 5 patients had low counts when stimulated by Con $\mathrm{A}$ including the 3 splenectomized patients. 3 patients had a poor response to PWM including 1 of the splenectomized patients. One patient had increased responses to Con $\mathrm{A}$ and PWM and another to PWM alone. Both of these patients still had their spleens.

\section{COMPARISON OF 12 PATIENTS BEFORE} AND AFTER SPLENECTOMY (TABLE 6)

Twelve patients were evaluated after splenectomy, after a mean of 27.6 months (Table 6). Mean haemoglobin values rose only slightly from $11 \cdot 8$ $13.0 \mathrm{~g} / \mathrm{d}$. However, the white cell count increased from a mean of 1.5 to $8.4 \times 10^{9} / 1(P<0.001)$, the increase being reflected both in the neutrophils $\left(0.4-4.2 \times 10^{9} / 1 ; \quad \mathrm{P}<0.01\right)$ and the lymphocyte $\left(0.8-4.0 \times 10^{9} / 1 ; \mathrm{P}<0.01\right)$. The platelet count rose from 130 to $407 \times 10^{9} / 1(\mathrm{P}<0.001)$. All patients had white cell counts $>4 \cdot 2 \times 10^{9} / 1$, neutrophil coun $>1.4 \times 10^{9} / 1$, and platelets $>220 \times 10^{9} / 1$ afte splenectomy. The mean ESR was reduced fro 72 to $53 \mathrm{~mm} / \mathrm{h}$ and the gammaglobulin level reduces from 22.6 to $20.3 \mathrm{~g} / \mathrm{l}$ after splenectomy.

Seven patients had bone marrow examinations before and after splenectomy, the mean interval after splenectomy being 30.6 months (Table 7) Cellularity was increased in all 7 before splenectom $\vec{x}$ and judged to be normal in 3 after splenectoms Increased granulopoiesis returned to normal 6 of the 7 after splenectomy. Erythropoiesis wos increased in 6 of 7 before splenectomy and returned to normal in 2 after splenectomy. Before splenectoms megakaryocytes were increased in 6 patients and decreased in the seventh, but afterwards were normal in 4 of the 6 and in the seventh. Stainabte

Table 6 Laboratory values in 12 patients before splenectomy and at follow-up

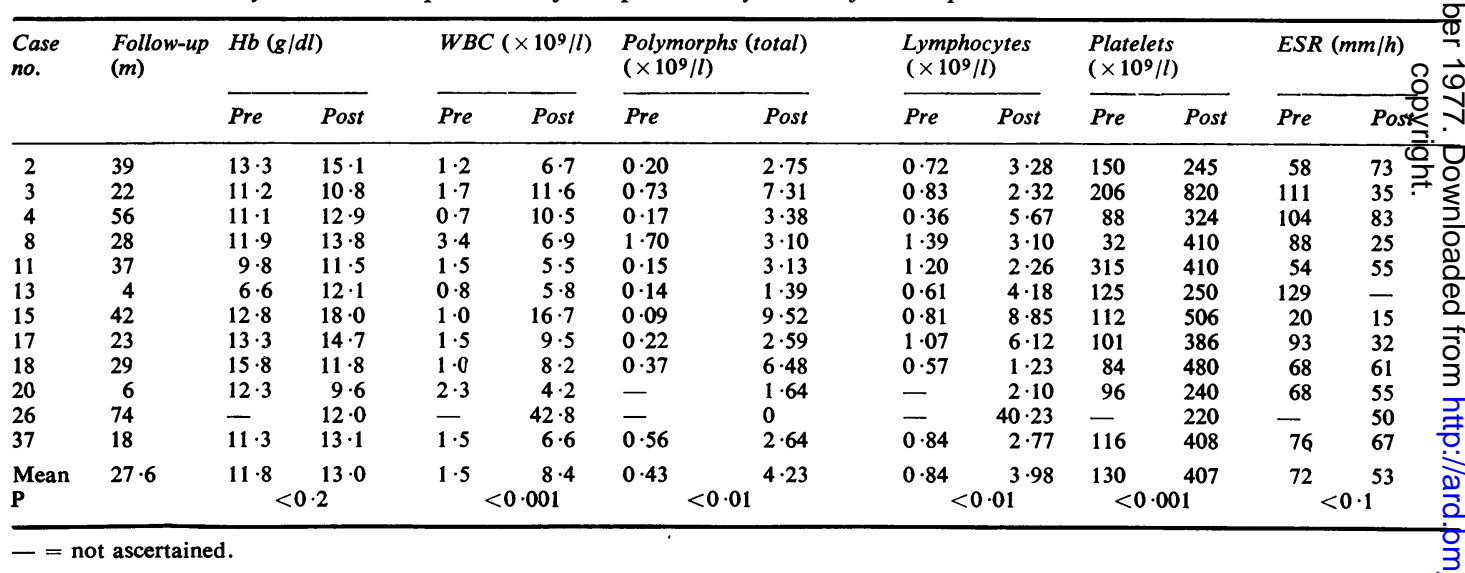

Table 7 Pre-and postsplenectomy bone marrow studies in 7 patients (pre- over postsplenectomy values)

\begin{tabular}{|c|c|c|c|c|c|c|}
\hline Case no. & $\begin{array}{l}\text { Months of } \\
\text { postsplenectomy }\end{array}$ & Cellularity & Granulopoiesis & Erythropoiesis & Iron & Megakaryocyte \\
\hline \multirow[t]{2}{*}{3} & \multirow[t]{2}{*}{22} & $\uparrow$ & $\uparrow$ & $\uparrow$ & 0 & $\uparrow$ \\
\hline & & $\mathbf{N}$ & $\mathbf{N}$ & $\mathbf{N}$ & 0 & $\uparrow$ \\
\hline \multirow[t]{2}{*}{4} & \multirow[t]{2}{*}{56} & $\uparrow$ & $\uparrow$ & $\uparrow$ & 0 & $\uparrow$ \\
\hline & & $\mathbf{N}$ & $\mathbf{N}$ & $\uparrow$ & 0 & $\mathbf{N}$ \\
\hline \multirow[t]{2}{*}{11} & \multirow[t]{2}{*}{37} & $\uparrow$ & $\uparrow$ & $\uparrow$ & 0 & $\uparrow$ \\
\hline & & $\uparrow$ & $\mathbf{N}$ & $\uparrow$ & 0 & $\mathbf{N}$ \\
\hline 15 & 42 & $\uparrow$ & $\mathbf{N}$ & $\mathbf{N}$ & $\mathbf{N}$ & $\mathbf{N}$ \\
\hline \multirow[t]{2}{*}{17} & \multirow[t]{2}{*}{23} & $\uparrow$ & $\uparrow$ & $\uparrow$ & 0 & $\uparrow$ \\
\hline & & NA & $\mathbf{N}$ & $\uparrow$ & NA & $\mathbf{N}$ \\
\hline \multirow[t]{2}{*}{18} & \multirow{2}{*}{5} & $\uparrow$ & $\uparrow$ & $\uparrow$ & 0 & $\uparrow$ \\
\hline & & $\uparrow$ & $\uparrow$ & $\uparrow$ & 0 & $\uparrow$ \\
\hline \multirow[t]{2}{*}{8} & \multirow{2}{*}{29} & $\uparrow$ & $\uparrow$ & $\uparrow$ & 0 & $\downarrow$ \\
\hline & & $\mathbf{N}$ & $\mathbf{N}$ & $\mathbf{N}$ & $2+$ & $\mathbf{N}$ \\
\hline
\end{tabular}


iron was absent in 6 of 7 patients before splenectomy and returned to normal in only 1,29 months after splenectomy.

\section{INFECTION}

Twenty-seven patients were diagnosed as having 41 episodes of infection. Of these, 8 underwent splenectomy. In most infection occurred between a few months and 2 years before splenectomy and was indeed the indication for splenectomy. Infections in the 27 patients tended to be due to common organisms (staphylococcus, streptococcus, haemophilus, and Gram-negative bacilli comprising $92 \%$ of the infections) and responded to usual antibiotic therapy. In 9 instances of 'clinical sepsis', consisting of fever and rigors, no specific infectious agent was isolated, but recovery occurred with antibiotic therapy. In the 8 patients who underwent splenectomy 17 episodes of infection occurred in 4 during a mean follow-up of $27 \cdot 6$ months. The type and location of infection had a similar distribution to those occurring before splenectomy. The other 4 have remained free of bacterial infection after a mean follow-up of 48 months, although 2 developed herpes zoster. 4 additional patients who had no prior infections underwent splenectomy. 1 died in the immediate postoperative period of Gramnegative sepsis. The other 3 have remained free of bacterial infection for a mean of 63 months.

Prednisone was taken by 22 patients, none receiving more than $15 \mathrm{mg} /$ day. Of 27 patients who had infection before splenectomy, 19 had received steroids compared with $3 / 7$ patients who developed no infections.

LEUCOCYTE KINETICS (TABLE 8)

We studied leucocyte kinetics by the coil test, which has been shown to express bone marrow neutrophil

Table 8 Results of coil test in patients with Felty's syndrome before and after splenectomy, in one $R A$ control and in 2 normal controls

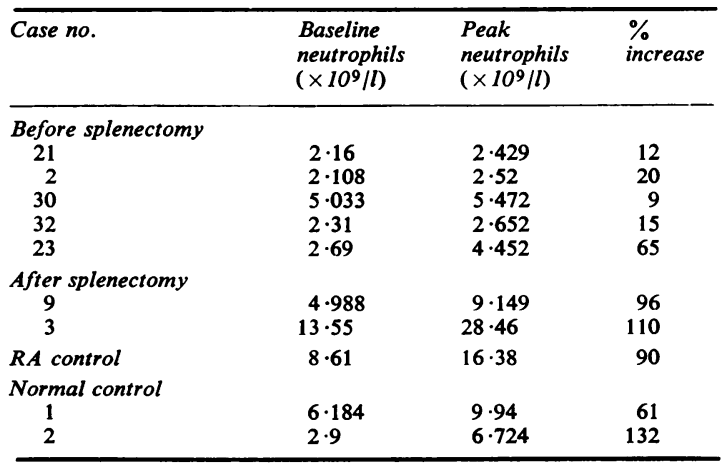

reserve (Brubaker and Nolph, 1971). Although our numbers are small, none of our patients with splenomegaly showed as great a neutrophil reserve as did the two patients with Felty's syndrome without spleens, and $4 / 5$ patients with splenomegaly had lower neutrophil reserves than the 3 control patients.

\section{Discussion}

Our experience shows that Felty's syndrome is a form of 'super' rheumatoid disease as reflected by the severity of joint disease, the prominence of extra-articular features, and a remarkable incidence of infections. Assessment of joint disease showed that patients had very destructive arthritis with a much higher incidence of deformities and bone and cartilage destruction than did a group of patients with definite or classical rheumatoid arthritis (Table 1). When compared to patients with severe rheumatoid disease, the group with Felty's syndrome showed a higher percentage of deformity $(91 \%$ vs $66 \%$ ) and of destruction on $x$-ray ( $74 \%$ vs $56 \%$ ).

We also found our Felty's patients to have more active (inflammatory) articular disease than the comparison group as reflected by the articular index and the percentage of patients with joint effusions $(77 \%)$ (Table 1$)$. This severe articular disease has not been emphasized in the past (Felty, 1924; Ruderman et al., 1968; Barnes et al., 1971; Louie and Pearson, 1971). Excluding the haematological features of Felty's syndrome, $94 \%$ of our patients had extra-articular features, with a mean of 2.9 per patient. This compares with an overall incidence of $76 \%$ in Gordon's group of hospitalized rheumatoid arthritis patients (Gordon et al., 1973). In comparing the three studies of Felty's syndrome (Table 3) it appears that nodules, splenomegaly, and lymphadenopathy are more frequent in these patients than in the large group of hospitalized rheumatoid patients.

The majority of patients with Felty's syndrome were anaemic $(79 \%)$ or leucopenic $(97 \%)$, but only $15 \%$ were thrombocytopenic. All but one patient in our series showed lymphocytopenia $\left(<1.5 \times 10^{9} / 1\right)$. In agreement with previous reports (Felty, 1924; Ruderman et al., 1968; Barnes et al., 1971; Louie and Pearson, 1971; Moore et al., 1971), bone marrow studies in these patients showed normal or increased cellularity in $74 \%$ and increased granulopoiesis in $90 \%$. In only 3 patients was decreased cellularity observed. Surprisingly, iron stores were absent in $67 \%$ and significantly reduced in a further $17 \%$, but an obvious site for blood loss was not found in the majority. Previous marrow studies in rheumatoid arthritis showed increased or normal 
iron staining (Raymond et al., 1965; Cartwright, 1966; Wardle and Attan, 1967; Douglas and Adamson, 1975). It is possible that in our series blood loss had occurred previously and stores had not been replenished, or that iron absorption was faulty in these patients.

Liver involvement occurred in at least onequarter of our patients (raised sulphobromophthalein in $27 \%$ ). However, pathological studies showed lobular hepatitis in 1, amyloidosis and haemangiomata in 1, and nonspecific findings in 5. Previous studies (Ritland, 1973; Blendis et al., 1974) have reported finding nodular regenerative hepatitis, cirrhosis, or lymphocytic infiltration of the sinusoids and portal triads in Felty's syndrome.

The kidney is often thought to be spared in rheumatoid disease, proteinuria being explained by complications such as urinary tract infections, amyloidosis, or as secondary to drug therapy. $39 \%$ of our patients excreted more than $500 \mathrm{mg}$ protein/24 hours in the absence of any other obvious cause for proteinuria. Histology in 3 patients showed focal glomerulonephritis in 2 and nephrosclerosis in 1. Whether this proteinuria is glomerular in origin (Baggenstoss and Rosenberg, 1943; Pollak et al., 1962; Brun et al., 1965) secondary to immune complex deposition, or tubular in origin secondary to an interstitial nephritis (Bulger et al., 1968) occasionally seen in rheumatoid arthritis cannot be answered without more pathological and immunofluorescent data. Light-chain excretion in the urine as described by Gordon et al. (1966) was not detected in 2 of our patients.

Many patients in all three studies of Felty's syndrome had raised immunoglobulin levels and a number of circulating autoantibodies (Table 4). The incidence of positive LE cells, rheumatoid factor, and antinuclear factor was greater in these patients than in other studies of rheumatoid arthritis (Ziff and Baum, 1972). Tests of cell-mediated immunity showed that 4 of 16 patients were anergic to a battery of skin tests but $T$ and $B$ cell counts and mitogen stimulation studies were near normal. Thus no constant defect in cell-mediated immunity was shown.

Twenty-seven patients were diagnosed as having episodes of infection, and 8 underwent splenectomy. Infections occurred within a few months to 2 years before splenectomy in most, and were usually the indication for splenectomy. Infections in the 27 patients tended to be due to common organisms and responded to usual antibiotic therapy. In the 8 patients who underwent splenectomy, 17 episodes of infection occurred during a mean follow-up of 27.6 months. The type and location of infection had a similar distribution to those occurring before splenectomy. As with previous studies, we also failed to show any correlation between severity of leucopenia and frequency or severity of infections. Thus, we could not explain the susceptibility of음 Felty's patients to infections by a quantitative defect of immunoglobulins, T cells, B cells, polymorpho- $\frac{\bar{T}}{-}$ nuclear cells, as suggested by Hurd et al. (1974), or尺 by other qualitative defects of the immune response.

We failed to show a correlation between severity of leucopenia and spleen size in agreement with Moore et al. (1971) and Ruderman et al. (1968). A $\vec{\omega}$ specific antileucocyte antibody, as described by? Faber and Elling (1966) and Calabresi et al. (1959),, might be implicated in the leucopenia of somew Felty's patients. Our kinetic studies suggest thatos Felty's patients with spleens have decreased neutro-i phil reserves. Bone marrow examinations in these patients show an exhaustion of the normal intra-s marrow reserves of mature neutrophils (a shift to the left). The 2 patients in whom we studied leucocyted kinetics after splenectomy showed normal neutrophilø reserves.

Splenectomy in our patients resulted in a sustained@ rise of white blood cell count, return of bone marrow to normal granulopoietic morphology, improvement of anaemia, and sustained rise $\mathrm{ff}_{\mathrm{f}}$ platelet counts. Splenectomy did not, however result in increased bone marrow iron stores nor did its significantly affect the incidence of infections. Ino fact, we cannot exclude the possibility that splen-क ectomy might have been instrumental in the fatal infection in one of our patients.

\section{References}

Baggenstoss, A. H., and Rosenberg, E. F. (1943). Viscera lesions associated with chronic infectious (rheumatoid) arthritis. Archives of Pathology, 35, 503-516.

Barnes, C. G., Turnbull, A. L., and Vernon-Roberts, B.3 (1971). Felty's syndrome. A clinical and pathologicab survey of 21 patients and their response to treatment Annals of the Rheumatic Diseases, 30, 359-374.

Bianco, C., Patrick, R., and Nussenzweig, N. (1970). AO population of lymphocytes bearing a membrane receptor for antigen-antibody-complement complexes. I. Separation and characterization. Journal of Experimental Medicine, 132, 702-720.

Blendis, L. M., Parkinson, M. C., Shilkin, K. B., and Williams, R. (1974). Nodular regenerative hyperplasia of the liver in Felty's syndrome. Quarterly Journal of Medicine, 43, 25-32.

Brubaker, L. H., and Nolph, K. D. (1971). Mechanisms ofo recovery from neutropenia induced by hemodialysis Blood, 38, 623-631.

Brun, C., Steem Olson, T., Raaschon, F., and Sorensen, A. W. S. (1965). Renal biopsy in rheumatoid arthritis? Nephron, 2, 65-81.

Bulger, R. J., Healey, L. A., and Polinsky, P. (1968). Renalo abnormalities in rheumatoid arthritis. Annals of the Rheumatic Diseases, 27, 339-344. 
Calabresi, P., Edwards, E. A., and Schilling, R. F. (1959). Fluorescent antiglobulin studies in leukopenic and related disorders. Journal of Clinical Investigation, 38, 2091-2100.

Cartwright, G. E. (1966). The anemia of chronic disorders. Seminars in Hematology, 3, 351-375.

Douglas, S. W., and Adamson, J. W. (1975). The anemia of chronic disorders: studies of marrow regulation and iron metabolism. Blood, 45, 55-65.

Faber, V., and Elling, P. (1966). Leukocyte specific antinuclear factors in patients with Felty's syndrome, rheumatoid arthritis, systemic lupus erythematosus and other diseases. Acta Medica Scandinavica, 179, 257-267.

Felty, A. R. (1924). Chronic arthritis in the adult associated with splenomegaly and leukopenia. Bulletin of the Johns Hopkins Hospital, 35, 16-20.

Gordon, D. A., Eisen, A. Z., and Vaughan, J. H. (1966). Studies on urinary gamma globulins in patients with rheumatoid arthritis. Arthritis and Rheumatism, 9, 575-588.

Gordon, D. A., Stein, J. L., and Broder, I. (1973). The extraarticular features of rheumatoid arthritis. A systematic analysis of 127 cases. American Journal of Medicine, 54, 445-452.

Greaves, M., Janossy, G., and Doenhoff, M. (1974). Selective triggering of human $T$ and $B$ lymphocytes in vitro by polyclonal mitogens. Journal of Experimental Medicine, 140, 1-18.

Hurd, E. R., Lo Spalluto, J., and Ziff, M. (1974). The role of immune complexes in production of the neutropenia of Felty's syndrome. (Abst.) Journal of Rheumatology, 1, Suppl., 105.

Jensen, D. P., Brubaker, L. H., Nolph, K. D., Johnson, C. A., and Nothum, R. J. (1973). Hemodialysis coilinduced transient neutropenia and overshoot neutrophilia in normal man. Blood, 41, 339-408.

Jondal, M., Holm, G., and Wigzell, H. (1972). Surface markers on human $\mathrm{T}$ and $\mathrm{B}$ lymphocytes. I. A large population of lymphocyte forming non-immune rosettes with sheep red blood cell. Journal of Experimental Medicine, 136, 207-215.

Kellgren, J. H., Jeffrey, M. R., and Ball, J. (1963). (Editors.) Atlas of Standard Radiographs of Arthritis. The Epidemiology of Chronic Rheumatism, Vol. 2. Blackwell, Oxford.

Lansbury, J. (1972). Methods for evaluating rheumatoid arthritis. Arthritis and Allied Conditions, Chapter 18. Ed. by J. L. Hollander and D. J. McCarty. Lea and Febiger, Philadelphia.

Louie, J. S., and Pearson, C. M. (1971). Felty's syndrome. Seminars in Hematology, 8, 216-220.

Moore, R. A., Brunner, C. M., Sandusky, W. R., and Leavell, B. S. (1971). Felty's syndrome: long-term followup after splenectomy. Annals of Internal Medicine, 75, 381-385.

Pollak, V. E., Pirani, C. L., Steck, I. E., and Kark, R. M. (1962). The kidney in rheumatoid arthritis: studies by renal biopsy. Arthritis and Rheumatism, 5, 1-9.

Raymond, F., Bowie, M. A., and Dugan, A. (1965). Iron metabolism in rheumatoid arthritis. Arthritis and Rheumatism, 8, 233-243.

Ritland, S. (1973). Cirrhosis of the liver in Felty's syndrome. Scandinavian Journal of Rheumatology, 2, 29-32.

Ruderman, M., Miller, L. M., and Pinals, R. S. (1968). Clinical and serologic observations on 27 patients with Felty's syndrome. Arthritis and Rheumatism, 11, 377-384.

Steinbrocker, O., Traeger, C. H., and Batterman, R. C. (1949). Therapeutic criteria in rheumatoid arthritis. Journal of the American Medical Association, 140, 659-660.

Wardle, E. N., and Attan, J. (1967). An electron microscope study of bone marrow in rheumatoid disease. British Journal of Haematology, 13, 194-201.

Ziff, M., and Baum, J. (1972). Laboratory findings in rheumatoid arthritis. Arthritis and Allied Conditions, Chapter 23. Ed. by J. L. Hollander and D. J. McCarty. Lea and Febiger, Philadelphia. 